\title{
Evaluation of Postinfection Control of Citrus Scab and Melanose with Benomyl, Fenbuconazole, and Azoxystrobin
}

\author{
P. M. Bushong and L. W. Timmer, senior biological scientist and professor, respectively, University of Florida, \\ Citrus Research and Education Center, 700 Experiment Station Road, Lake Alfred 33850
}

\begin{abstract}
Bushong, P. M., and Timmer, L. W. 2000. Evaluation of postinfection control of citrus scab and melanose with benomyl, fenbuconazole, and azoxystrobin. Plant Dis. 84:1246-1249.

Citrus scab, caused by Elsinoe fawcettii, and melanose, caused by Diaporthe citri, are serious diseases of citrus in Florida that reduce the exterior quality of fruits produced for the fresh market. The availability of fungicides with postinfection activity could increase the flexibility of growers in managing these diseases. The effectiveness of benomyl at $0.96 \mathrm{~g}$ a.i./liter, fenbuconazole at $120 \mathrm{mg}$ a.i./liter, and azoxystrobin at $235 \mathrm{mg}$ a.i./liter was evaluated on rough lemon seedlings for scab and on grapefruit for melanose. Potted seedlings in the greenhouse were pruned to stimulate formation of uniform susceptible shoots, which were inoculated and kept moist for $16 \mathrm{~h}$. Fungicides were applied prior to inoculation and at various intervals from 16- to 96-h postinoculation and subsequently evaluated for disease intensity. All three fungicides were effective as preinoculation sprays for scab control. Benomyl was effective if applied up to $72 \mathrm{~h}$ after inoculation, and fenbuconazole and azoxystrobin were effective if applied within 16 to $48 \mathrm{~h}$ after inoculation. For melanose, azoxystrobin was highly effective as a preventive spray but benomyl and fenbuconazole were not. None of the fungicides was very effective for melanose control as postinfection treatments. Use of postinfection sprays under field conditions appears to be promising for scab control but not for melanose control.
\end{abstract}

Citrus scab, caused by Elsinoe fawcettii Bitancourt \& Jenk., and melanose, caused by Diaporthe citri F.A. Wolf, are serious diseases that reduce the external quality of citrus fruits produced for the fresh market (9). Scab affects grapefruit, lemon, and many tangerines and tangerine hybrids. Melanose affects all types of citrus but is especially severe on grapefruit. Control of these diseases requires several fungicide applications, beginning at first flush for scab and after bloom for melanose and continuing until mid-summer. Copper products are the only fungicides registered for control of melanose, and only copper fungicides, ferbam, and benomyl are recommended for scab control (3). Resistance to benomyl in E. fawcettii developed many years ago (19), but the fungicide is still effective in many locations and is still recommended for scab control (3).

Conidia of E. fawcettii are produced on acervuli on scab pustules on fruits or leaves within 1 to $2 \mathrm{~h}$. After dispersal, conidia germinate and infect young tissues within 2 to $3 \mathrm{~h}(10,16)$. In the field, scab pustules produced on the spring growth

Corresponding author: L. W. Timmer

E-mail: 1wt@lal.ufl.edu

Florida Agricultural Experiment Station Journal Series No. R-07424.

Accepted for publication 18 July 2000.

Publication no. D-2000-0831-01R

(c) 2000 The American Phytopathological Society flush serve as inoculum for infection of fruits, which are susceptible for 6 to 8 weeks after petal fall. Fungicides such as benomyl or ferbam that have eradicant activity (12) are recommended for use after emergence of vegetative growth in the spring and after petal fall (3). Copper fungicides, which have only protectant action (12), are applied $\approx 3$ to 4 weeks after petal fall.

Conidia of D. citri, the causal agent of melanose, are produced only on dead twigs. After dispersal by rain water, infection occurs within 8 to $10 \mathrm{~h}$ at an optimum temperature of $\approx 25^{\circ} \mathrm{C}(4,10)$. Only protectant copper fungicides are recommended for control of melanose (3). On grapefruit, applications are made approximately every 3 weeks from petal fall until the fruit becomes resistant, approximately 3 months after petal fall. Fungicides are not usually applied for control of melanose on leaves because protectant fungicides are not very effective for disease control on rapidly expanding leaf tissue and little benefit is derived from disease control on vegetative tissues.

No sterol-biosynthesis-inhibiting (SBI) or strobilurin fungicide has ever been registered for control of foliar fungal diseases of citrus. In contrast to the situation for citrus, a wide range of fungicides are registered and used for control of foliar fungal diseases of many deciduous tree and small fruit crops. Protectant fungicides, such as captan, chlorothalonil, and dithiocarbamates, have been registered for many years. During the late 1960s and 1970s, benomyl, a systemic fungicide, was demonstrated to have postinfection activity and was found to reduce inoculum of several foliar fungal diseases of deciduous fruits $(5,7)$. During the late 1970s, SBI fungicides were developed and subsequently registered for use on many fruit crops. These fungicides, such as propiconazole, triforine, fenbuconazole, tebuconazole, and fenarimol, have protectant and localized systemic activity in the apoplast. SBI fungicides have postinfection activity and provide control even when applied after a weather event favorable for disease development $(2,5,7,8$, 22). Even if symptom development is not prevented, SBI fungicides may prevent sporulation and, thus, reduce subsequent disease $(5,6,22)$. More recently, strobilurin fungicides have been developed $(1,23)$, and some have been registered for use on fruit crops. These products also have locally systemic activity in the cuticle and leaf boundary areas and have postinfection activity against many foliar fungal diseases $(1,23)$.

Limited research has been conducted on the mechanism of action of fungicides against citrus scab and melanose. Whiteside (17) demonstrated that copper fungicides were strictly protectants for control of melanose. Benomyl had limited activity as a protectant but did effectively reduce production of pycnidiospores on dead twigs (17). Timmer and Zitko (12) demonstrated that ferbam and fenbuconazole, but not copper fungicides, had eradicant activity on existing lesions of citrus scab.

The postinfection activity of fungicides against citrus scab and melanose has not been investigated. The possibility of making applications after an infection period would allow growers greater flexibility in their disease control programs, especially in emergency situations. The purpose of this study was to investigate the existence and duration of postinfection activity of fungicides for scab and melanose control. For our investigation, we selected benomyl, a registered true systemic fungicide; fenbuconazole, a locally systemic SBI fungicide that currently has an emergency registration for use on grapefruit in Florida; and azoxystrobin, a locally systemic strobilurin fungicide that may be registered in the near future.

\section{MATERIALS AND METHODS}

Plant materials. Potted seedlings of rough lemon (Citrus jambhiri Lush), which are highly susceptible to all pathotypes of E. fawcettii (11), were used for evaluations of control of citrus scab. Grapefruit $(C$. 
paradisi Macf.) seedlings, which are highly susceptible to D. citri, were used for melanose tests. Seedlings were grown in soilless potting mix in 2.5-liter plastic pots until they were $\approx 1.0 \mathrm{~m}$ tall. Plants were pruned back to $0.5 \mathrm{~m}$ to force growth of shoots of uniform size and age. Two to four uniform shoots were selected on each plant, and all other foliage was removed prior to inoculation.

Inoculum preparation. Isolate R-36 of E. fawcettii, originally isolated from Temple orange near Lake Placid, FL, was used for most inoculations. For evaluations of benomyl, isolate LeF92, originally isolated from grapefruit near Bowling Green, FL, was used. Both isolates are of the Florida Broad Host Range pathotype (11) and are highly pathogenic to rough lemon. R-36 is completely resistant to benomyl at $10 \mu \mathrm{g} / \mathrm{ml}$, whereas LeF92 is sensitive to benomyl. Inoculum was prepared as described by Whiteside (18) by first removing a $1-\mathrm{mm}^{2}$ piece of mycelium from an actively growing culture of E. fawcettii on potato dextrose agar and crushing it with a sterile spatula in an empty petri dish. Liquid Fries medium was poured into the dishes, and mycelial fragments were stirred into the medium. Dishes were incubated in the dark at room temperature $\left(21\right.$ to $24^{\circ} \mathrm{C}$ ) for $48 \mathrm{~h}$. The liquid medium was poured off the microcolonies adhering to the bottom of the dish, and the colonies were washed three times with sterile distilled water, covered with autoclaved lake water, and incubated for $24 \mathrm{~h}$ in the dark for conidia production. Conidia in lake water were added to sterile distilled water, and the concentration was adjusted to $\approx 5 \times 10^{4}$ conidia per $\mathrm{ml}$.

Isolate S-22 of D. citri, obtained from G. E. Brown (Florida Department of Citrus, Lake Alfred), was used for all melanose experiments. For pycnidia production, mature citrus twigs $\approx 3$ to $6 \mathrm{~mm}$ in diameter were collected from the field, cut into 5- to 7-cm-long segments, and autoclaved. Sterilized twigs were placed in petri dishes and partially covered with potato dextrose agar. Agar plugs with mycelia were transferred to plates, and the cultures were incubated for 30 to 45 days at $25^{\circ} \mathrm{C}$ for pycnidia production. Conidia exuding from pycnidia were collected with a sterile needle and suspended in distilled water. Conidia were washed three times in sterile distilled water by centrifugation to remove the mucilaginous slime that inhibits germination. The concentration was adjusted to $\approx 10^{5}$ conidia per $\mathrm{ml}$, and orange juice was added to a final concentration of $1 \%(\mathrm{vol} / \mathrm{vol})$ as described by Whiteside (17).

Treatments and evaluations. In most experiments, fungicides were applied 1 day prior to inoculation and at $16,24,48$, and $72 \mathrm{~h}$ after inoculation and compared with a nonsprayed control. In some experiments, a 96-h postinoculation treatment also was included. All fungicides were evaluated at the rates recommended by the manufacturer for experimental evaluation. Benomyl (Benlate $50 \mathrm{WP}$ ) was applied at $960 \mathrm{mg}$ a.i./liter; fenbuconazole (Enable $2 \mathrm{~F}$ ) was applied at 120 mg a.i./liter; and azoxystrobin (Abound 2.08 SC) was applied at $235 \mathrm{mg}$ a.i./liter. Plants

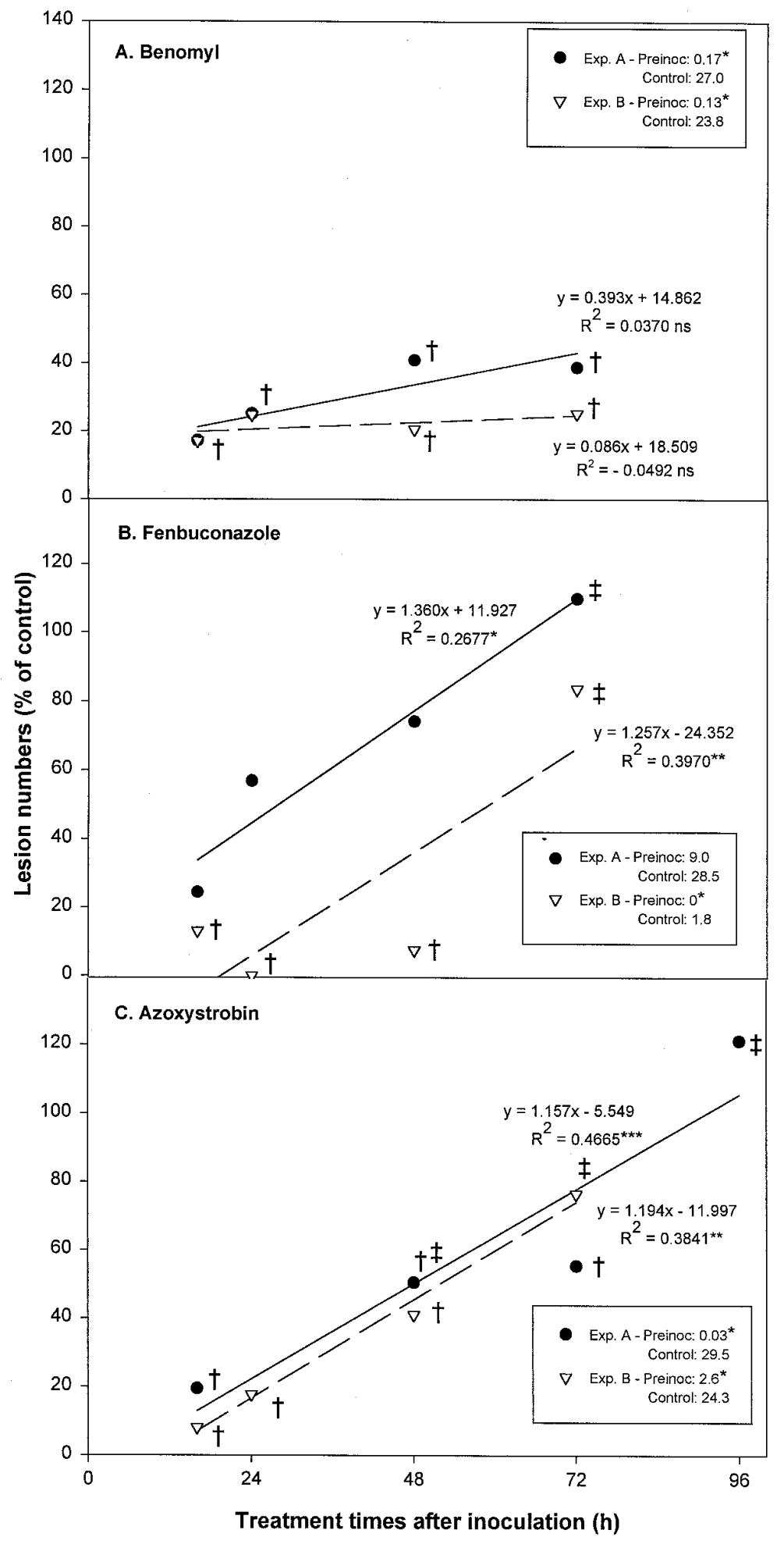

Fig. 1. Control of citrus scab caused by Elsinoe fawcettii with pre- and postinoculation applications of (A) benomyl, (B) fenbuconazole, and (C) azoxystrobin. The number of lesions per leaf in the control and preinoculation treatment are given in the boxes. An * indicates that the preinoculation treatment is significantly $(P \leq 0.05)$ different from the unsprayed control. In the postinoculation treatments, a $\dagger$ indicates that a point is significantly $(P \leq 0.05)$ different from the control, and a $\ddagger$ indicates that a value is significantly $(P \leq 0.05)$ different from the preinoculation treatment, according to the $t$ test. were sprayed to run-off using a hand-pump sprayer. Five single-plant replications were used for each treatment.

Plants were inoculated by spraying the ing a chromatography sprayer (Crown Sprā new foliage with a conidial suspension, us- 
Tool, North American Professional Products, Woodstock, IL). Plants were covered with premoistened thin plastic bags and placed in a mist bed in the greenhouse under ambient temperature $\left(\approx 20\right.$ to $\left.30^{\circ} \mathrm{C}\right)$ and light conditions. The outside of the bags was misted for $20 \mathrm{~s}$ every $5 \mathrm{~min}$ to keep the plants and bags moist for $16 \mathrm{~h}$. After $16 \mathrm{~h}$ of incubation, plants were placed in the greenhouse, and postinfection fungicide treatments were applied as indicated above. Each experiment was conducted at least twice.

Plants were placed in the greenhouse for $\approx 10$ days to allow symptom development.
For citrus scab, the number of individual lesions was counted on each leaf that was present at the time of inoculation. Results were expressed as the average number of lesions per leaf on each plant. For melanose, each leaf present at the time of inoculation was rated on a scale of 0 to 4 , where $0=$ no lesions, $1=1$ to 10 lesions, $2=11$ to 100 lesions, $3=101$ to 1,000 lesions, and $4=$ confluent lesions. Results were expressed as the average rating for each plant.

Statistical analysis. Data in each experiment were subjected to analysis of variance using the GLM procedure (SAS

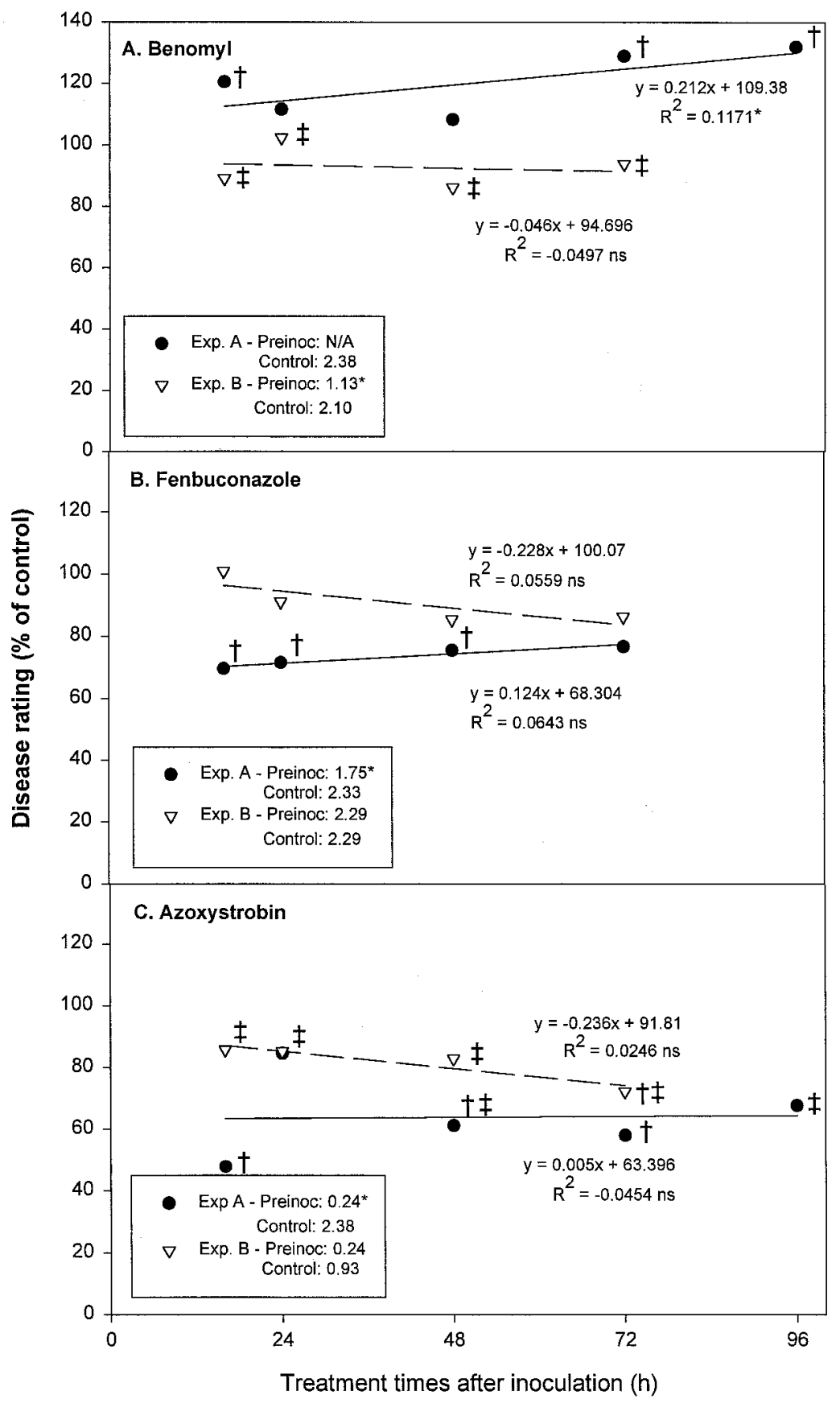

Fig. 2. Control of melanose caused by Diaporthe citri with pre- and postinoculation applications of (A) benomyl, (B) fenbuconazole, and (C) azoxystrobin. The disease ratings for the control and preinoculation spray are given in the boxes. An * indicates that the pretreatment is significantly $(P \leq$ $0.05)$ different from the control. In the postinoculation treatments, a $\dagger$ indicates a value is significantly $(P \leq 0.05)$ different than the unsprayed control, and a $¥$ indicates that it is significantly $(P \leq$ 0.05 ) different from the preinoculation treatment according to the $t$ test.
Institute, Inc., Cary, NC). Mean lesion counts or ratings between individual treatments were compared using the $t$ test at $P \leq 0.05$. Data from the postinfection treatments were converted to the percentage of the control values and regressed against time to determine whether postinfection effects changed with time after inoculation.

\section{RESULTS}

Citrus scab. Benomyl applied before inoculation was highly effective in controlling scab in both experiments (Fig. 1A). Postinfection treatments significantly reduced scab compared with the unsprayed control up to $72 \mathrm{~h}$ after inoculation. None of the treatments after inoculation was significantly less effective than the preinoculation spray. Regression analyses did not indicate that control diminished with time after inoculation for up to $72 \mathrm{~h}$.

Fenbuconazole was effective for scab control when applied as a preventive treatment and significantly reduced scab compared with the unsprayed control in one experiment (Fig. 1B). The difference between the preinoculation spray and the control in experiment A was significant only at $P \leq$ 0.10 . Postinfection applications of fenbuconazole reduced disease intensity only in the 16-h treatment in experiment $\mathrm{A}$, in which disease intensity was high, and for up to $48 \mathrm{~h}$ in experiment $\mathrm{B}$, in which severity was lower. Applications at 72-h postinfection were not effective. Regression analysis also indicated that postinoculation control with fenbuconazole diminished with time.

Preinoculation application of azoxystrobin was highly effective in reducing scab intensity (Fig. 1C). Applications made up to $48 \mathrm{~h}$ after inoculation significantly reduced scab intensity. Regression analyses indicated that the degree of control diminished significantly with time after application. However, in two other experiments in which scab intensity was low (fewer than five lesions per leaf), azoxystrobin controlled disease as well at $72 \mathrm{~h}$ after inoculation as in the pretreatment (data not shown).

Melanose. Benomyl applied before inoculation significantly reduced disease intensity in one experiment but was not highly effective (Fig. 2A). The preinoculation treatment was not included in the other experiment. In experiment A, melanose intensity was significantly greater in the benomyl treatments than in the control at 16,72 , and $96 \mathrm{~h}$ after inoculation. In experiment $\mathrm{B}$, no postinoculation treatment was significantly different from the control, and all resulted in significantly more disease than the preinoculation spray. Melanose intensity increased with time after inoculation at which the fungicide was applied in experiment $\mathrm{A}$, but the $R^{2}$ was low, and there was no significant effect of time in experiment B.

Preinoculation applications of fenbuconazole significantly reduced melanose severity 
in one of two experiments (Fig. 2B). Postinoculation sprays significantly reduced melanose in experiment A compared with the control at all times after inoculation. However, disease was reduced by only $\approx 20$ to $25 \%$. In experiment $\mathrm{B}$, none of the postinoculation treatments was significantly different from the control or the pretreatment.

Azoxystrobin applied prior to inoculation significantly reduced melanose compared with the unsprayed control in one experiment (Fig. 2C). Postinfection applications of azoxystrobin were only weakly effective. In experiment $\mathrm{A}$, most treatments applied after inoculation were significantly different from the control but only reduced disease by $\approx 40 \%$. In experiment $B$, postinoculation treatments did not reduce disease intensity in most cases.

\section{DISCUSSION}

Benomyl, fenbuconazole, and azoxystrobin were effective as protectant and postinfection sprays for citrus scab. These types of fungicides have been similarly effective for foliar fungal pathogens of other fruit crops. Benomyl, applied as a postinfection spray, was effective in preventing symptom development of apple scab and in reducing inoculum production (5). Postinfection activity has been studied extensively with SBI fungicides. Hildebrand and McRae (2) found that triforine had excellent activity up to $48 \mathrm{~h}$ after infection and was still effective at $90 \mathrm{~h}$ after infection against mummy berry disease of blueberry. Monilinia blossom blight of sour cherry was effectively controlled by applications of several SBI fungicides for up to $48 \mathrm{~h}$ after inoculation (22). Many SBI fungicides have good postinfection and antisporulant activity against apple scab even when applied up to $120 \mathrm{~h}$ after inoculation $(5,6)$. Postinfection activity has not been extensively studied with strobilurin fungicides, but given their locally systemic nature, some activity would be expected $(1,23)$. In the present study, postinfection activity against citrus scab was detected up to $\approx 72 \mathrm{~h}$ after infection.

In previous studies, benomyl and fenbuconazole were highly effective as protectants against citrus scab $(13,20,21,24)$ and as eradicants of the fungus in old scab lesions (12). In this study, these fungicides were highly effective in preventing symptom development after infection as well. We previously demonstrated that azoxystrobin can control scab when applied as a protectant (15). It is evident that this fungicide also is active when applied as a postinfection spray. These fungicides could be applied to the spring flush of growth to act as protectants and also prevent lesion formation even if infection had already occurred by reducing inoculum production on leaves and making the disease easier to control on fruits.

For melanose, the three fungicides evaluated had little or no activity against the disease when applied after inoculation. In previous work, benomyl was not highly effective when applied as a protectant, but it did reduce inoculum production (17). Fenbuconazole reduced melanose when applied as a protectant but was not highly effective (24). Thus, perhaps it was not surprising that benomyl and fenbuconazole were ineffective as postinfection sprays. In previous studies, kresoxim-methyl, another strobilurin fungicide, and azoxystrobin were effective against melanose when applied as protectants $(14,25)$. Azoxystrobin, however, was only weakly effective as a postinfection spray in the present study. Because postinfection fungicide applications were not very effective on leaves, we presume control on fruits would likewise be ineffective. Melanose may be a difficult disease to control with postinfection sprays. The symptoms on leaves and fruits are the result of a host reaction, and the fungus does not develop extensively in lesions as does the scab fungus (9). D. citri can be reisolated from lesions for only a few days after symptom development. Thus, even if a fungicide kills the pathogen in the early stages of infection, symptom development could proceed uninhibited.

In a disease management program, the three fungicides evaluated here may be useful as postinfection sprays for scab but not for melanose. Copper fungicides and ferbam are often used as protectants for scab control. It is desirable to have fungicides available that can be applied after an infection period. In cases where an unanticipated infection period occurs some time after the last protectant spray, severe damage can be avoided. Postinfection sprays should be limited to emergency situations, because such applications may increase the risk of development of fungicide resistance, as has occurred in the past with benomyl (19).

\section{ACKNOWLEDGMENTS}

This project was funded in part by the Florida Citrus Production Research Advisory Council, Project 981-20. We thank A. J. Tesoriero for technical assistance.

\section{LITERATURE CITED}

1. Baldwin, B. C., Clough, J. M., Godfrey, C. R. A., Godwin, J. R., and Wiggins, T. E. 1996. The discovery and mode of action of ICI A5504. Pages 69-77 in: Modern Fungicides and Antifungal Compounds. H. Lyr, P. E. Russell, and H. D. Sister, eds. Intercept, Andover, Hants, UK.

2. Hildebrand, P. D., and McRae, K. B. 1995. Protectant and postinfection activity of triforine against ascospore infections of Monilinia vaccinii-corymbosi in lowbush blueberries. Can. J. Plant Pathol. 17:215-222.

3. Knapp, J. L., ed. 2000. 2000 Florida Citrus Pest Management Guide. Univ. Florida. Inst. Food Agric. Sci. Publ. No. SP-43.

4. Kuramoto, T. and Yamada, S. 1975. The influence of environmental factors on the infection of citrus melanose caused by Diaporthe citri (Faw:) Wolf. Bull. Fruit Tree Res. Stn. B-2:75-86.

5. O'Leary, A. L., and Sutton, T. B. 1986. Effects of postinfection applications of ergosterol biosynthesis-inhibiting fungicides on lesion formation and pseudothecial development of Venturia inaequalis. Phytopathology 76:119-124.

6. Schwabe, W. F. S., Jones, A. L., and Jonker, J. P. 1984. Greenhouse evaluation of curative and protective action of sterol-inhibiting fungicides against apple scab. Phytopathology 74:249-252.

7. Szkolnik, M. 1978. Techniques involved in greenhouse evaluation of deciduous tree fruit fungicides. Annu. Rev. Phytopathol. 16:103-129.

8. Szkolnik, M. 1979. Postinfection evaluation of fungicides in the greenhouse for apple scab control. Fungic. Nematicide Tests 35:21.

9. Timmer, L. W. 1999. Diseases of fruit and foliage. Pages 107-115 in: Citrus Health Management. L. W. Timmer and L. W. Duncan, eds. The American Phytopathological Society, St. Paul, MN

10. Timmer, L. W., Garnsey, S. M., and Graham, J. H. 2000. Compendium of Citrus Diseases. 2nd ed. The American Phytopathological Society, St. Paul, MN.

11. Timmer, L. W., Priest, M., Broadbent, P., and Tan, M. K. 1996. Morphological and pathological characterization of species of Elsinoe causing scab disease of citrus. Phytopathology $86: 1032-1038$.

12. Timmer, L. W., and Zitko, S. E. 1993. Techniques for greenhouse evaluation of fungicides for control of citrus scab. Pages 125-129 in: Proc. IV Congr. Int. Soc. Citrus Nurserymen. E. Rabe, ed. South African Citrus Nurserymen's Association.

13. Timmer, L. W., and Zitko, S. E. 1997. Evaluation of fungicides for control of Alternaria brown spot and citrus scab. Proc. Fla. State Hortic. Soc. 110:71-76.

14. Timmer, L. W., and Zitko, S. E. 1998. Evaluation of fungicides for control of melanose on grapefruit, 1997. Fungic. Nematicide Tests 54:554-555.

15. Timmer, L. W., and Zitko, S. E. 1999. Evaluation of fungicides for control of citrus scab on Duncan grapefruit, 1998. Fungic. Nematicide Tests 54:553.

16. Whiteside, J. O. 1975. Biological characteristics of Elsinoe fawcettii pertaining to the epidemiology of sour orange scab. Phytopathology 65:1170-1175.

17. Whiteside, J. O. 1977. Sites of action of fungicides in the control of citrus melanose. Phytopathology 67:1067-1072.

18. Whiteside, J. O. 1978. Pathogenicity of two biotypes of Elsinoe fawcettii to sweet orange and some other cultivars. Phytopathology 68: 1128-1131.

19. Whiteside, J. O. 1980. Detection of benomyltolerant strains of Elsinoe fawcettii in Florida citrus groves and nurseries. Plant Dis. 64:871872 .

20. Whiteside, J. O. 1981. Evolution of current methods for citrus scab control. Proc. Fla. State Hortic. Soc. 94:5-8.

21. Whiteside, J. O. 1990. Prospects for improved control of citrus scab with fungicide spray treatments. Proc. Fla. State Hortic. Soc. 103:4-7.

22. Wilcox, W. 1990. Postinfection and antisporulant activities of selected fungicides in control of blossom blight of sour cherry caused by Monilinia fructicola. Plant Dis. 74:808-811.

23. Ypema, H. L., and Gold, R. E. 1999. Kresoxim-methyl: Modification of a naturally occurring compound to produce a new fungicide. Plant Dis. 83:4-17.

24. Zitko, S. E., and Timmer, L. W. 1997. Evaluation of fungicides for control of citrus scab and melanose on grapefruit, 1996. Fungic. Nematicide Tests 53:490.

25. Zitko, S. E., and Timmer, L. W. 1998. Comparison of BAS 490F and Kocide 101 for control of melanose on grapefruit, 1995. Fungic. Nematicide Tests 53:489. 